\title{
Intrinsic vulnerability assessment for the Quaternary aquifer in Baghdad area using DRASTIC model
}

\author{
Inass Abdal Razaq Al-Mallah ${ }^{1}$. Wasan Sabeh Al-Qurnawi ${ }^{1}$
}

Received: 8 January 2018 / Accepted: 12 June 2018 / Published online: 11 August 2018

(c) The Author(s) 2018

\begin{abstract}
The assessment of groundwater vulnerability to pollution considered an effective tool in managed water resources especially in arid and semi-arid areas. The main objective of this study is to appraise the vulnerability for the Quaternary aquifer in Baghdad region, by using DRASTIC model and GIS for both the standard and pesticide conditions to evaluate the most sensitive and effective areas to pollution. The vulnerability index map for the standard and pesticide conditions shows three classes of very low, low, and moderate and low, moderate, and high classes, respectively, where the DRASTIC pesticide index ratio represents 33\% more than the DRASTIC standard index. The results showed that the most vulnerable areas of the standard condition were constructed in two regions, the North West part and the second area that represented in the middle part of the study area, besides the high pesticide vulnerable index with $48 \%$ of the study area at the same parts. Topography, soil media, and water depth are the main factors that affect the groundwater contamination of the Quaternary aquifer and make it more susceptible to pollution; therefore, it is necessary to maintain these susceptible areas from agricultural results, seepage, and effluent from the residual wastes which spilt from the uncontrolled industries distributed in the area.
\end{abstract}

Keywords Iraq $\cdot$ Baghdad $\cdot$ Quaternary $\cdot$ Groundwater $\cdot$ Vulnerability $\cdot$ DRASTIC

\section{Introduction}

The vulnerability studies are considered good approaches to improve good information on preventing the deterioration of the environment (Mendoza and Barmen 2006). Aquifer vulnerability provides a good overview of the environmental evaluation of the economic impacts of the wastes in highly vulnerable areas. Moreover, they are providing useful information for decision making and management the water resources, monitoring and protecting the groundwater quality (Hamamin 2011). The vulnerability maps were considered as essential in protecting groundwater and a valuable tool in environmental management (Daly and Warren 1998).

The present study is concentrated on Baghdad city, the capital of Iraq, which located at the central part of it. The city is divided into two main parts by Tigris River which passes through it, the eastern part Al-Rusafa, and the western part called Al-Karkh (Al-Hiti 1985) (Fig. 1), because

Inass Abdal Razaq Al-Mallah

anosa1974@yahoo.com

1 Geology Department, College of Science, University

of Basrah, Basrah, Iraq of the environmental importance of this province, and the very rapid growing in population that increased recently, it is necessary to evaluate the environmental deterioration of Baghdad city environment due to misuse of the groundwater.

\section{Study area}

The study area has an environmental and economic importance according to the last statistical percentages, and there are many land uses can be identified where the urbanised, agricultural, and industrial areas have percentages of 72.69, 25 , and $2.31 \%$ from the total area, respectively, (Ali et al. 2013), besides the very rapid growing population that increased recently (Ali 2012). For those reasons of the increase in population and misuse of lands in addition to digging irregular groundwater wells, it has to identify the vulnerability map of Baghdad area using DRASTIC method with GIS tools, to explain the zonation of areas that have high and low groundwater susceptible to pollution. 
Fig. 1 Location map of the study area (prepared by the authors)

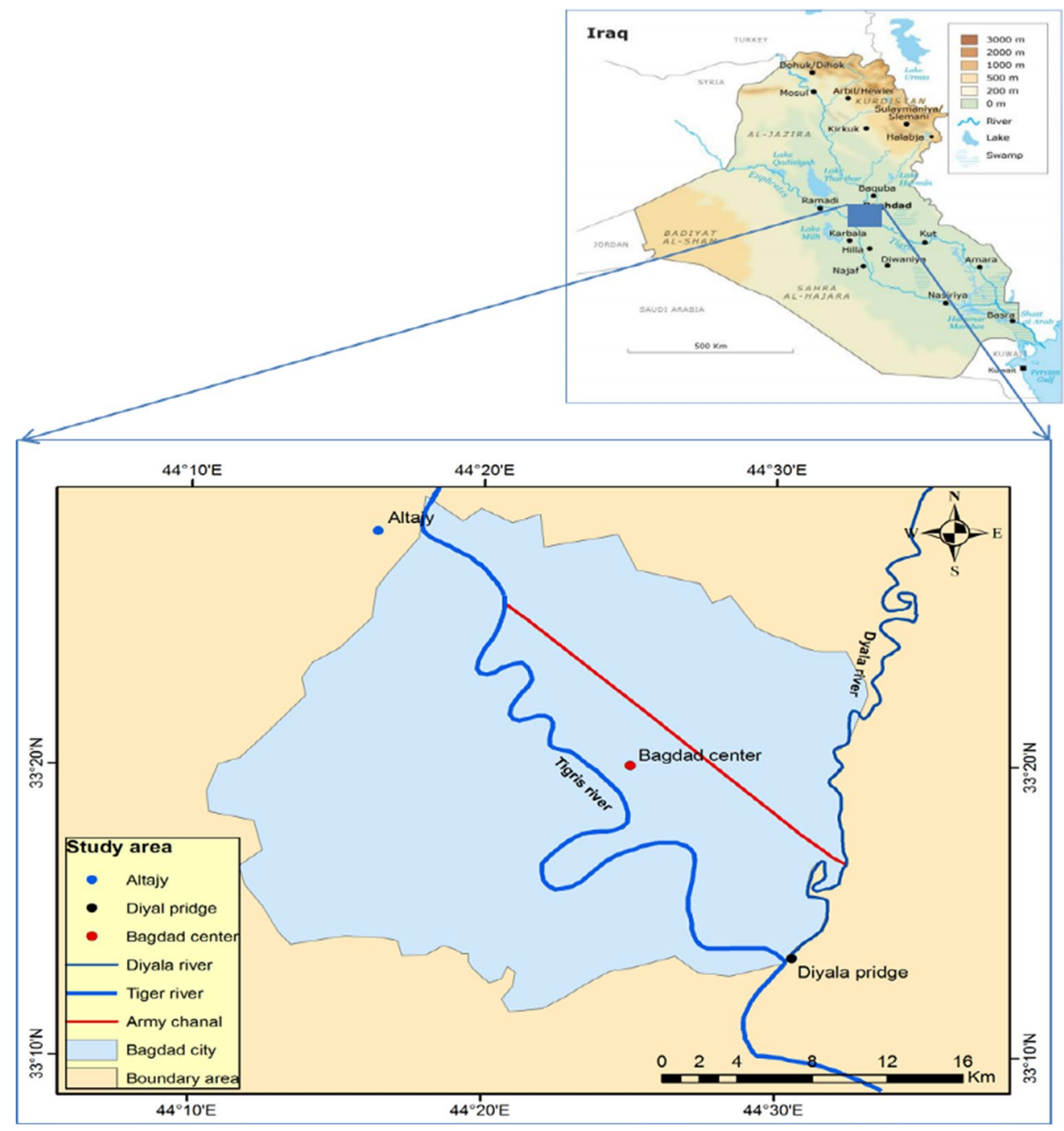

\section{Geologic and geomorphologic setting}

The study area is covered by Quaternary sediments of the Mesopotamian plain; the Quaternary sediments are differentiated into three groups. Baghdad lies into Holocene sediments group which include mainly from floodplain deposits, anthropogenic deposits, and marsh deposits consisting of alternating sand, silt, and clay, and gravel in vertical and lateral variations (Fig. 2) (Jassim and Goff 2006). Baghdad can be considered as semi-arid to arid climate influencing typically by the gas emitted from automobile exhausts (Awadh 2015). The elevation, referenced to the sea level, of the area ranges $(0-40 \mathrm{~m})$, (Fig. 3). The land surface is generally flat with imperceptible gradient from northwest to southeast (Yacoub 2011).

\section{Hydrogeological setting}

The study area is covered by Quaternary sediments, which formed by rapidly alternating horizons of clay, silty clay, clayey silt, silt, sand, and gravel. Clay and silt form the aquitards, while sand and gravel form the aquifers (AlJiburi and Al-Basrawi 2011). The Quaternary sediments have laterally and vertically abrupt lithological changes. Therefore, no homogenous lithological units exist throughout the area, so the sediment has been considered regionally as a lithologically complex aquifer system (Al-Jiburi and Al-Basrawi 2011; Araim 1990). Generally, the groundwater flow map of the study area shows that the direction of the groundwater flow has two main directions, at Karkh side, the flow patterns are from northwest towards south and southeast, whereas at Rasafa side, the flow direction is from northeast towards southwest of the study area (Tigris River). The piezometric surface of the groundwater within the area according to the archival database from Baghdad Ground Water Directorate shows many local flow directions may appear in the area depending on the relation with the surface water and the lithological variations throughout the study area (Fig. 4). 
Fig. 2 Geological Map of the study area. (modified from GEOSURV, 2011)

Fig. 3 Digital elevation model, DEM, of the study area
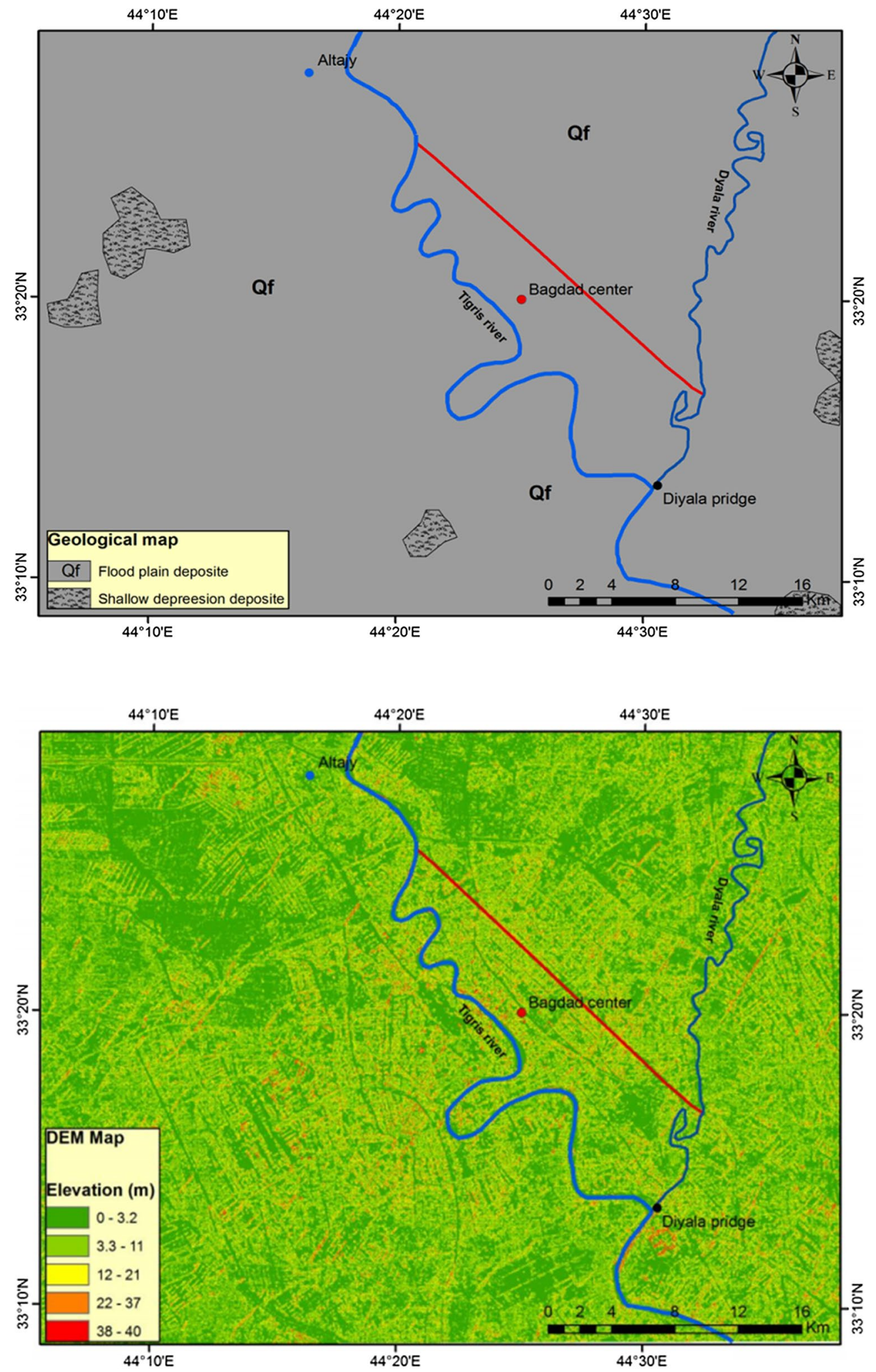
Fig. 4 Groundwater flow map of the study area

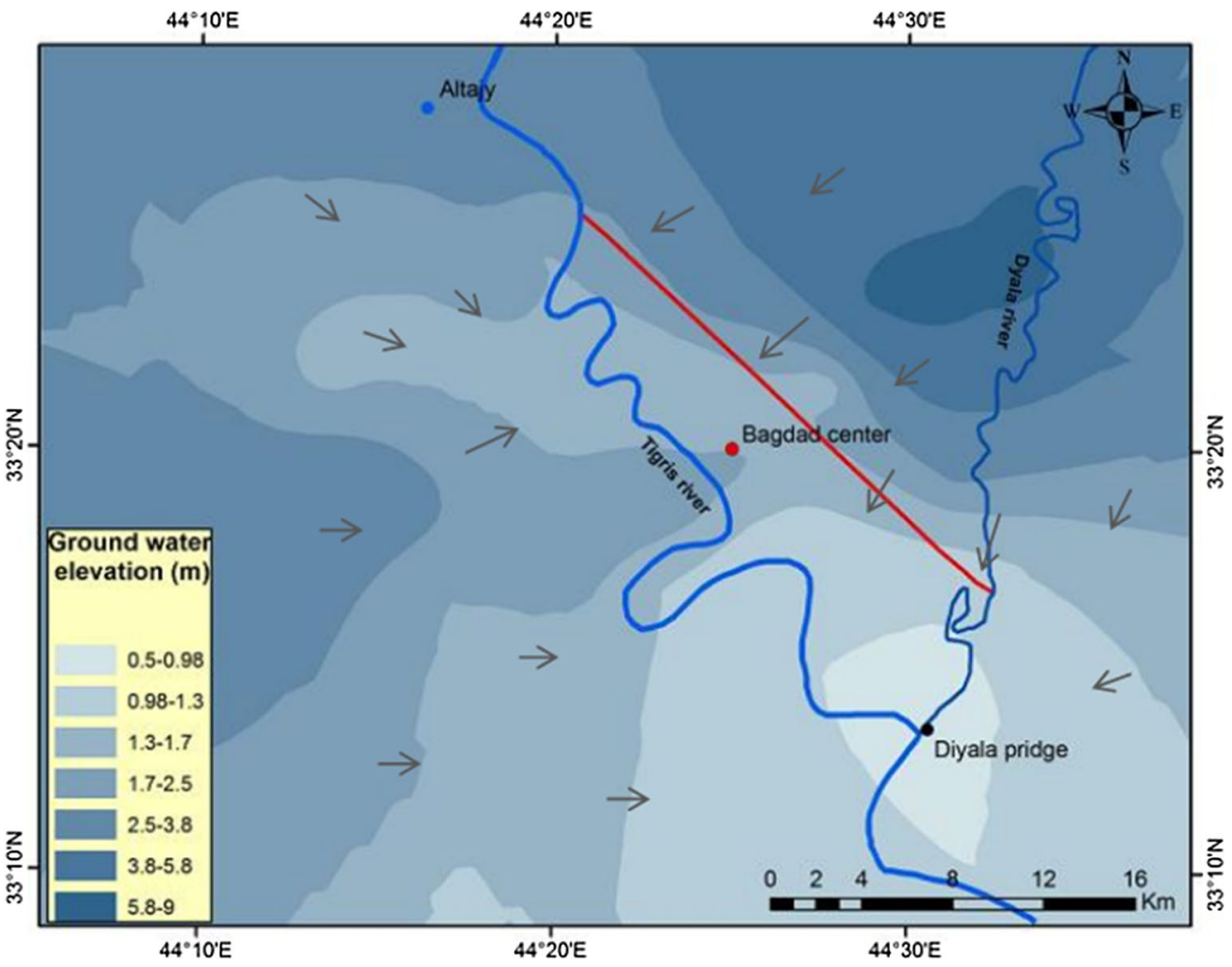

\section{Materials and methods}

Data from Baghdad Ground Water Directorate of 35 wells taken from the archival of Groundwater Directory, where obtained to prepare the spatial distribution of all the maps necessary for the DRASTIC model like depth to water, net recharge, aquifer media, hydraulic conductivity. In addition, the grain size analyses of 22 soil samples were taken from the same studied area according to (Ali 2012).

DRASTIC is one of the most widely used models to assess groundwater vulnerability. The name DRASTIC represents the use of the first letter of each hydrological component in calculating the vulnerability index, $(D)$ depth to water, $(R)$ net recharge, $(A)$ aquifer media, $(S)$ soil media, $(T)$ topography, $(I)$ impact of vadose zone media, and $(C)$ hydraulic conductivity of the aquifer. These parameters control the groundwater contamination potential. The DRASTIC ranking system contains three major parts: Range, Rating, and Weight: (Aller et al. 1987).

Range: each factor in DRASTIC assigned in ranges or significant media type which have an impact on pollution potential.

Rates: each range for each DRASTIC factor is evaluated with respect to each other to determine the relative significance of each range with respect to the impact on pollution potential. The rating for each DRASTIC factor is assigned a value between 1 and 10 . The higher rating is the more significant on pollution potential.
Weights: each DRASTIC factor is evaluated with respect to each other to determine the relative importance of each factor. Each factor is assigned a relative weight ranging from 1 to 5 , Table 1 shows that the most significant factor is allocated 5 and the least significant is allocated 1. DRASTIC has two weight classifications, one for normal (standard) conditions and the other for conditions with intense agricultural activity which represent as Pesticide Index.

The weighted ratings are summed to obtain the DRASTIC index DI (AL-Qurnawi 2014), as follows:

$\mathrm{DI}=D_{\mathrm{r}} D_{\mathrm{w}}+R_{\mathrm{r}} R_{\mathrm{w}}+A_{\mathrm{r}} A_{\mathrm{w}}+S_{\mathrm{r}} S_{\mathrm{w}}+T_{\mathrm{r}} T_{\mathrm{w}}+I_{\mathrm{r}} I_{\mathrm{w}}+C_{\mathrm{r}} C_{\mathrm{w}}$

Table 1 Weights of the factors in the DRASTIC (Normal and Pesticides) scenarios. (Reproduced with the permission from Aller et al. 1987)

\begin{tabular}{lll}
\hline Factors & DRASTIC \\
\cline { 2 - 3 } & Normal & Pesticides \\
\hline$D:$ depth to groundwater & 5 & 5 \\
$R:$ net recharge & 4 & 4 \\
$A:$ aquifer media & 3 & 3 \\
$S:$ soil media & 2 & 5 \\
$T:$ topography & 1 & 3 \\
$I:$ impact of Vadose zone & 5 & 4 \\
$C:$ hydraulic conductivity of the & 3 & 2 \\
aquifer & & \\
\hline
\end{tabular}


where DI DRASTIC index, $D_{\mathrm{r}}$ rating for the depth to water table, $D_{\mathrm{w}}$ weights assigned to the depth to water table, $\mathrm{Rr}$ rating for ranges of aquifer recharge, $R_{\mathrm{w}}$ weight for the aquifer recharge, $A_{\mathrm{r}}$ ratings assigned to aquifer media, Aw weights assigned to aquifer media, $S_{\mathrm{r}}$ ratings for the soil media, $\mathrm{Sw}$ weights for soil media, $T_{\mathrm{r}}$ ranges for topographic (slop), $T_{\mathrm{w}}$ weights assigned to topography, Ir ratings assigned to vadose zone, $I_{\mathrm{w}}$ weights assigned to vadose zone, $C_{\mathrm{r}}$ ratings for hydraulic conductivity, $C_{\mathrm{w}}$ weights given to hydraulic conductivity.

Aller et al. (1987) did not propose any classification for their DRASTIC results, so the vulnerability ranges of the DRASTIC index used in this study correspond to the most commonly used references in the literature (Civita and De Regibus 1995; Corniello et al. 1997) Table 2.

\section{Development of the DRASTIC vulnerability index for the study area}

To apply the DRASTIC method in the study area, the base information and data of the area should be provided and prepared for each seven thematic maps. The data were gathered from different sources such as, geological and meteorological data, a digital elevation model DEM, archival database from Baghdad Ground Water Directorate, and grain size analyses. ArcGIS 10 software was used to compile the geospatial data, to compute the DRASTIC index, and to generate the final vulnerability maps. The different data and maps are converted into UTM system zone $38 \mathrm{~N}$.

A model grid over the aquifer was then overlaid and assigned DRASTIC rating to the grid cell for each of the seven hydrogeological factors. The raster grid of cell size $10 \mathrm{~m}(x, y)$ forming 5048 and 4061 columns and rows, respectively, is used.

\section{Application of the DRASTIC method for the study area}

Depth to groundwater levels $(D)$ is the distance between the surface and the water table, which is ranged between 1 and $9 \mathrm{~m}$ in the shallow upper aquifer. This distance was obtained from the well logs, hydrological reports of groundwater wells data obtained from Baghdad Ground

Table 2 Criteria of the degrees of vulnerability. (Reproduced with the permission from Civita and De Regibus 1995; Corniello et al. 1997)

\begin{tabular}{ll}
\hline $\begin{array}{l}\text { Degree of } \\
\text { vulnerability }\end{array}$ & DRASTIC index \\
\hline$<80$ & Very low \\
$80-120$ & Low \\
$120-160$ & Moderate \\
$160-200$ & High \\
$>200$ & Very high \\
\hline
\end{tabular}

Water Directorate, and the groundwater depth thematic map is interpolated between the well locations by using kriging method and then reclassified into three classes using reclassify command in spatial analyst and regard to rating DRASTIC system (Fig. 5; Table 3).

Net recharge $(R)$ represents the considered annual recharge for the study area depending on (Bashoo et al. 2005), which corresponding to the estimated magnitude by applying chloride mass balance method, the amount of recharge was less than $50 \mathrm{~mm}$ represents for all the study area and assigned to rating value 1 , as well as, the weighted value was 4 , (Table 3; Fig. 6)

Aquifer media (A) The main lithological material for the shallow unconfined aquifer in the study area consists of sand, gravel and a significant amount of silt (Ali 2012; Salman et al. 1990); therefore, the rating value for aquifer media is eight (Fig. 7).

Soil media (S) Soil media could be described as a layer over the unsaturated zone. The thickness of the soil media varies from zero to $1.5 \mathrm{~m}$ in depth. The soil media thematic map of the basin was prepared from the hydrological soil group (HSG) classification of the grain size analyses of the study area. The infiltration rates of the soil site were interpolated by using kriging method and then reclassified into the HSG of the area for $A, B, C$ and $D$ types.

The hydrological soil properties and their compositions are defined by USDA with other relevant factor depending on the twelve soil texture Table 4, (USDA 1975). According to the hydrological soil groups classification (Table 4), the hydrological soil texture is classified as shown in Table 5, we recognise four hydrological group of the study area, and the USDA triangle is shown in Fig. 8, while Table 6 represents the classification of hydrological soil group (HSG) for each soil sample. The areal distribution of each soil group is used to estimate the infiltration rate for the soil sites in the study area Table 6 . Figure 9 represents the soil media rating for the area; the choosing rate value for $A, B, C$, and $D$ group is $9,6,4$, and 3, respectively.

Topography (slope $T$ ) refers to the slope variability of the land surface (Aller et al. 1987). Areas with low slope tend to retain water longer and this allows a greater infiltration of recharge water and a greater potential for contaminant migration (Baalousha 2006). Slop was calculated in term of percentage using the Digital Elevation Model DEM covering the study area. The obtained percentage slope values are reclassified according to slope index ranges which are reclassified according to rating values, and thematic map of the slope rating for the study area is shown in (Fig. 10).

Impact of vadose zone (I) To drive the thematic map for the vadose zone to the shallow unconfined aquifer, assigned ratings depending on well log information of the selected wells. Therefore, the vadose zone for the study 
Fig. 5 Rating of groundwater depth map of the study area

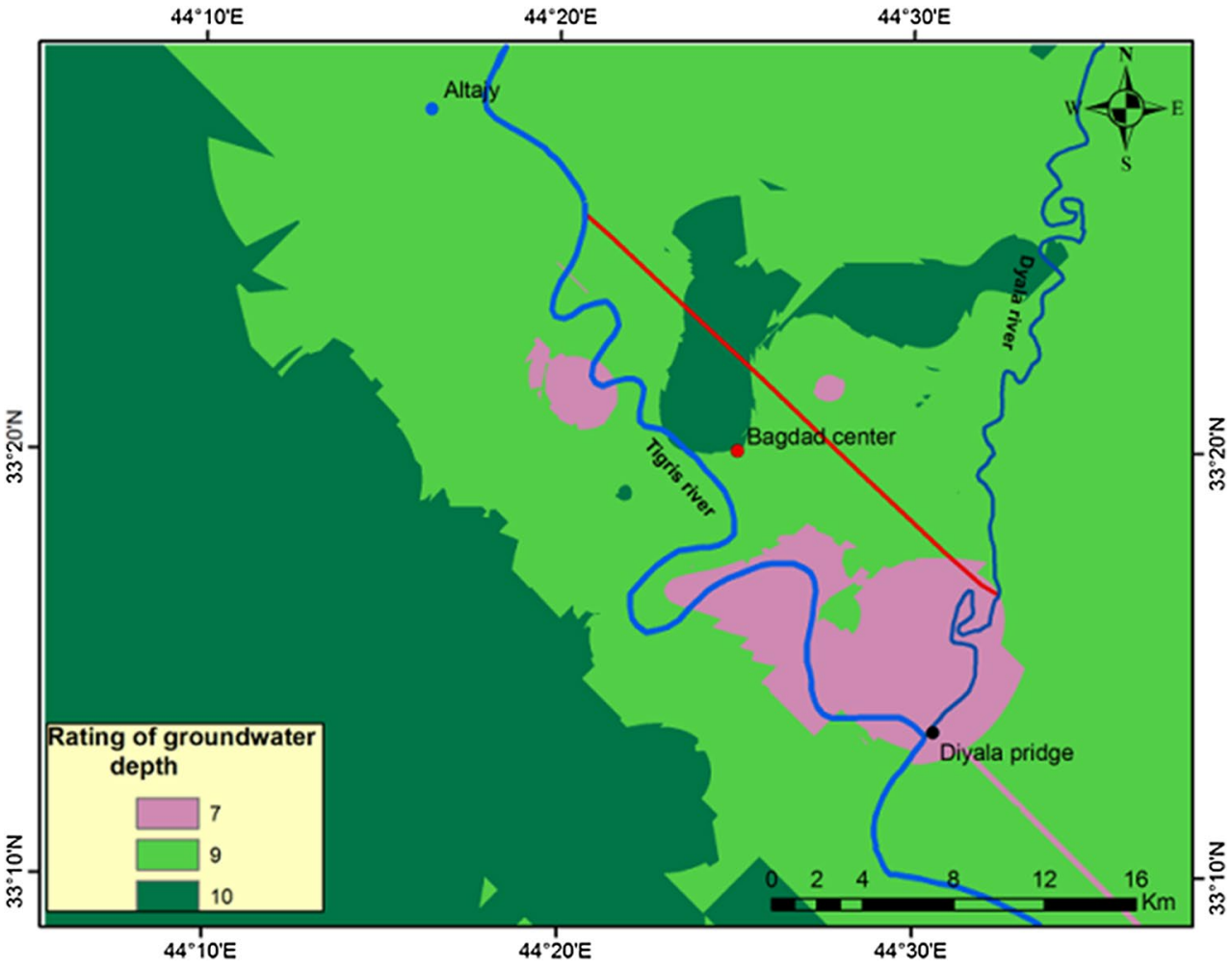

\begin{tabular}{|c|c|c|c|c|c|c|}
\hline \multirow[t]{2}{*}{ DRASTIC items } & \multirow[t]{2}{*}{ Range } & \multirow[t]{2}{*}{ Rating } & \multicolumn{2}{|l|}{ Weight } & \multicolumn{2}{|c|}{$\begin{array}{l}\text { Total weight (rat- } \\
\text { ing } \times \text { weight) }\end{array}$} \\
\hline & & & Standard & Pesticides & Standard & Pesticides \\
\hline Groundwater depth(m) & $\begin{array}{l}0-1.5 \\
1.5-4.5 \\
4.5-9\end{array}$ & $\begin{array}{l}10 \\
9 \\
7\end{array}$ & 5 & 5 & $\begin{array}{l}50 \\
45 \\
35\end{array}$ & $\begin{array}{l}50 \\
45 \\
35\end{array}$ \\
\hline Net recharge $(\mathrm{mm})$ & $<50$ & 1 & 4 & 4 & 4 & 4 \\
\hline Aquifer media & Sand and gravel & 8 & 3 & 3 & 24 & 24 \\
\hline Soil media & $\begin{array}{l}A \\
B \\
C \\
D\end{array}$ & $\begin{array}{l}10 \\
8 \\
6 \\
4\end{array}$ & 2 & 5 & $\begin{array}{l}20 \\
16 \\
12 \\
8\end{array}$ & $\begin{array}{l}50 \\
40 \\
30 \\
20\end{array}$ \\
\hline Topography slop \% & $\begin{array}{l}0-3 \\
3-6 \\
6-11 \\
>18\end{array}$ & $\begin{array}{l}10 \\
9 \\
5 \\
1\end{array}$ & 1 & 3 & $\begin{array}{l}10 \\
9 \\
5 \\
1\end{array}$ & $\begin{array}{l}30 \\
27 \\
15 \\
3\end{array}$ \\
\hline Impact of vadose zone & Sand-gravel & 7 & 5 & 4 & 35 & 28 \\
\hline Hydraulic conductivity (m/d) & $<4$ & 1 & 3 & 2 & 3 & 2 \\
\hline
\end{tabular}

area assigned for the all aquifer at rating number 7 which consist of sand, silt and gravel (Fig. 11).

Hydraulic conductivity $(C)$ The hydraulic conductivity values were obtained from the field measurements on test drilling boreholes from archive and documents published by (Al-Jiburi 2009) and represent for the hole aquifer in the study area (Fig. 12) and reclassified according to the criteria of DRASTIC model with rating at 1 .

\section{The results}

To produce the final vulnerability map (standard and pesticides), the raster calculator is used in spatial analyst tool. Each rating thematic layer is multiplied by the weighting values for each parameter according to Table 1 . Then, the seven thematic layers put together according 
Fig. 6 Rating of net recharge map of the study area

Fig. 7 Rating of aquifer media map of the study area
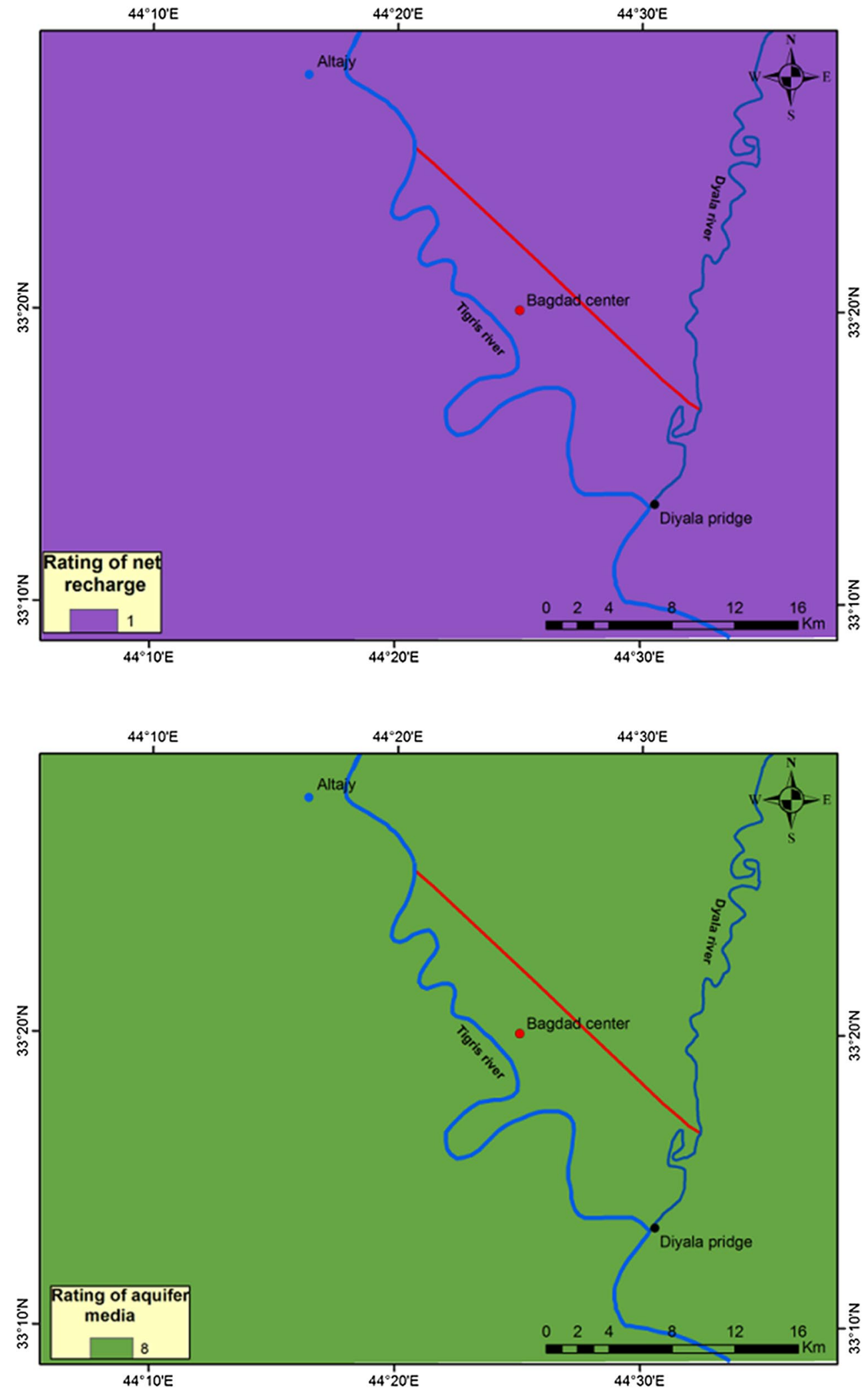

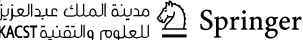


Table 4 SCS hydrological soil group by USDA (1986)

\begin{tabular}{|c|c|c|}
\hline Soil group & Description & $\begin{array}{l}\text { Final infiltration } \\
\text { rate }(\mathrm{mm} / \mathrm{h})\end{array}$ \\
\hline A & Lowest runoff potential. Include deep sands with very little silt and clay, also deep, rapidly permeable loess & $8-12$ \\
\hline$B$ & $\begin{array}{l}\text { Moderately low runoff potential. Mostly sandy soils less deep than } A \text {, and less deep or less aggregated than } A \text {, } \\
\text { but the group as a whole has above-average infiltration after thorough wetting }\end{array}$ & $4-8$ \\
\hline C & $\begin{array}{l}\text { Moderately high runoff potential. Comprises shallow soils and soils containing considerable clay and colloids, } \\
\text { though less than those of group } D \text {. The group has below-average infiltration after presaturation }\end{array}$ & $1-4$ \\
\hline$D$ & $\begin{array}{l}\text { Highest runoff potential. Includes mostly clays of high selling per cent, but the group also includes shallow } \\
\text { soils with nearly impermeable subhorizons near the surface }\end{array}$ & $0-1$ \\
\hline
\end{tabular}

Table 5 Hydrological soil properties classified by soil texture. (Reproduced with the permission from Rawls et al. 1982)

\begin{tabular}{lll}
\hline Texture class & $\begin{array}{l}\text { Effective water capacity } \\
(\mathrm{cm} / \mathrm{cm})\end{array}$ & $\begin{array}{l}\text { SCS } \\
\text { hydrological } \\
\text { grouping }\end{array}$ \\
\hline Sand & 0.35 & $A$ \\
Loamy sand & 0.31 & $A$ \\
Sandy loam & 0.25 & $B$ \\
Loam & 0.19 & $B$ \\
Silt loam & 0.17 & $C$ \\
Silt & 0.15 & $C$ \\
Sandy clay loam & 0.14 & $C$ \\
Clay loam & 0.14 & $D$ \\
Silty clay loam & 0.11 & $D$ \\
Sandy clay & 0.09 & $D$ \\
Silty clay & 0.09 & $D$ \\
Clay & 0.08 & $D$ \\
\hline
\end{tabular}

to Eq. (1) to generate the vulnerability index map. The results are shown in (Fig. 13) for the standard conditions and (Fig. 14) which represent the vulnerability index for pesticides conditions.

The vulnerability index map for the standard conditions shows three vulnerable classes of very low, low, and moderate with class area of $(110.5,747.15$, and 1088.8$) \mathrm{km}^{2}$, respectively; the very low zone is constructed at the southeast part of Al-Resafa area with vulnerability index less than 80 , while the high vulnerable index (140) were occupied the most area of Al-Karkh region in addition to the middle and northwest parts of Al-Resafa area (Table 7)

The pesticides DRASTIC model is ranged between 110 and 200 , which are higher by $33 \%$ than the standard conditions with low, moderate, and high classes of $(27.2,982.5$, and 936.6$) \mathrm{km}^{2}$, respectively (Table 7; Fig. 14). The results confirm that $48 \%$ of the study area is occupied by high pesticides in DRASTIC index distribution in the middle and northwest of the study area. The distribution of vulnerability classes through the area is related to the variation on the impact of recharge and low values of hydraulic conductivity.
Table 8 shows the statistical summary of the seven factors maps used to compute the DRASTIC index, the high risk of groundwater contamination in the area affected by topography, soil media and water depth factors with standard deviation of $(2.29,2.25$, and 1.72), respectively. The other factors imply low risks of contamination.

\section{Sensitivity analysis}

According to Leal and Castillo (2003), the sensitivity analysis is important to test the validity of aquifer vulnerability methods to reduce subjectivity in the selection of rating ranges and to increase reliability.

The main objective of sensitivity analysis is to assess the influence of rating values and weights assigned to each parameter. This will helps to judge the significance of subjective elements (Gogu and Dassargues 2000). Performing sensitivity analysis has been described by many authors, where the vulnerability is computed several times; and in each time one parameter is removed (Gogu and Dassargues 2000; Napolitano and Fabbri 1996).

In this study area, the DRASTIC vulnerability themes were computed seven times and, in each time, one item was removed. In order to assess the influence of sensitivity to removing one parameter, Babiker et al. (2005) suggested the following expression to measure the sensitivity influence $\mathrm{Si}$ as:

$S_{i}=\left|\frac{v}{N}-\frac{v^{\prime}}{n}\right|$

where $S_{i}$ is the sensibility of DRASTIC parameter, $v$ is the DRASTIC vulnerability index, $v^{\prime}$ is the DRASTIC vulnerability index after removing one parameter, $\mathrm{N}$ is the total number of parameters or layers used in obtaining the DRASTIC vulnerability (equals 7), $n$ is the total number of parameters or layers used in obtaining the DRASTIC vulnerability after removing one parameter (equals 6).

Table 9 illustrates the statistics on sensitivity of removing one DRASTIC parameter on the obtained vulnerability values. The sensitivity influence results show that the most 
Fig. 8 Soil texture of the soil samples (USDA online web)

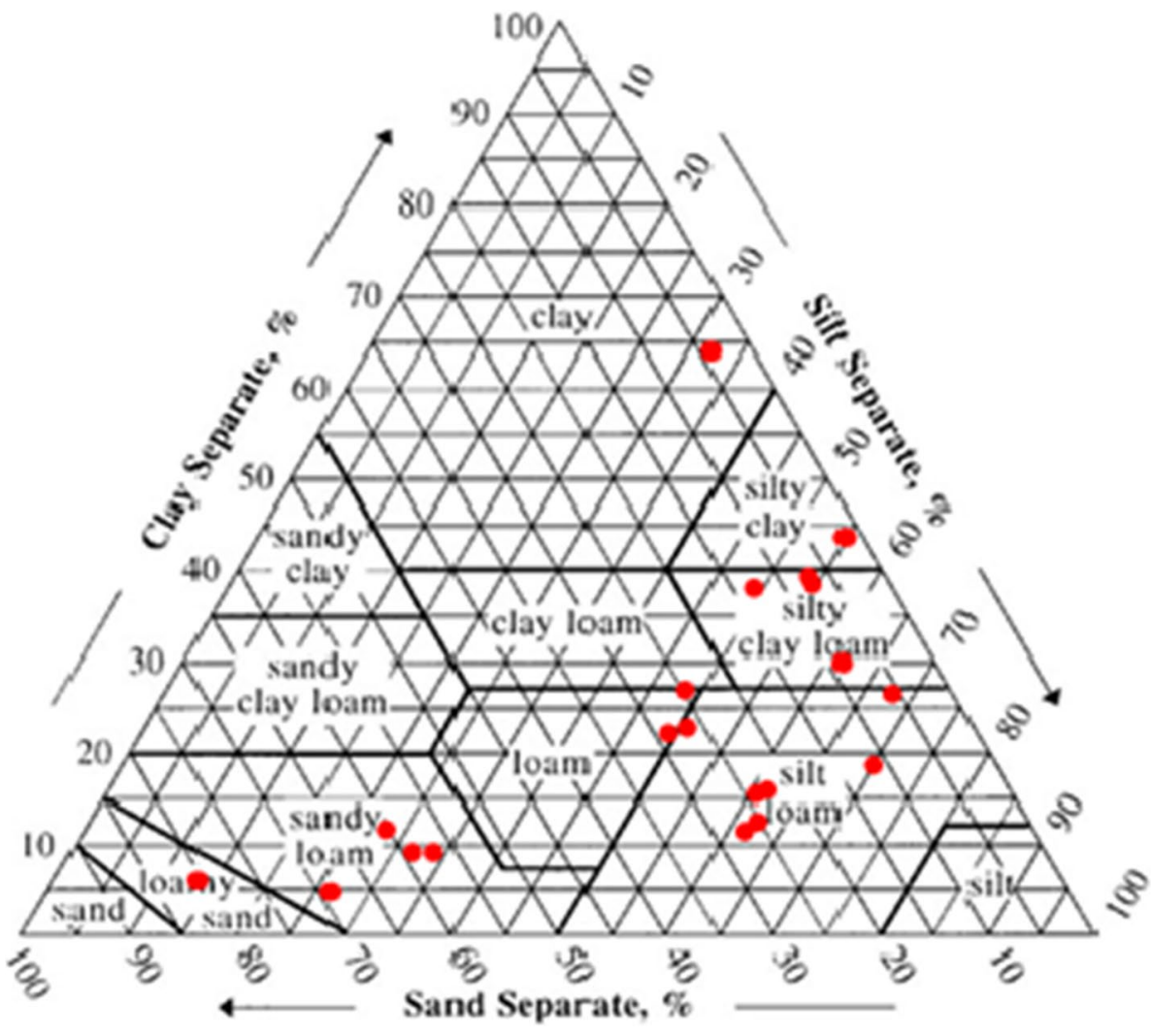

Table 6 The classification of hydrological soil groups (HSG) for the soil sites in the study area

\begin{tabular}{lclllll}
\hline Soil no. & Sand $(\%)$ & Silt $(\%)$ & Clay $(\%)$ & Texture & Hyd. group & $\begin{array}{l}\text { Infiltration } \\
\text { rate }(\mathrm{mm} / \mathrm{h})\end{array}$ \\
\hline S1 & 9.6 & 61 & 29.4 & Silt & $D$ & 1 \\
S2 & 8.5 & 55 & 36.5 & Silt & $D$ & 1 \\
S3 & 4.73 & 63.67 & 31.6 & Silt & $D$ & 1 \\
S4 & 81.74 & 12.73 & 5.53 & Silty sand & $A$ & 10 \\
S5 & 2.6 & 54.2 & 43.2 & Mud & $D$ & 1 \\
S6 & 25.67 & 47.8 & 26.53 & Sandy mud & $B$ & 6 \\
S7 & 6.73 & 67.2 & 26.07 & Silt & $C$ & 3 \\
S8 & 58 & 33.27 & 8.73 & Silty sand & $B$ & 6 \\
S9 & 60 & 31.27 & 8.73 & Silty sand & $B$ & 6 \\
S10 & 8 & 53.2 & 38.8 & Mud & $D$ & 1 \\
S11 & 8.07 & 53.13 & 38.8 & Mud & $D$ & 3 \\
S12 & 12.47 & 69.4 & 18.13 & Sandy silt & $C$ & 1 \\
S13 & 13.73 & 48.6 & 37.67 & Sandy mud & $D$ & 1 \\
S14 & 2.53 & 54.27 & 43.2 & Mud & $D$ & 3 \\
S15 & 26.13 & 60.74 & 12.13 & Sandy silt & $C$ & 6 \\
S16 & 61.34 & 27.53 & 11.13 & Silty sand & $B$ & 6 \\
S17 & 70 & 25.67 & 4.33 & Silty sand & $B$ & 3 \\
S18 & 23.6 & 62 & 15.4 & Sandy silt & $C$ & 3 \\
S19 & 25 & 60 & 15 & Sandy silt & $C$ & $B$ \\
S20 & 29.73 & 48.53 & 21.74 & Sandy silt & $B$ & 6 \\
S21 & 28 & 61 & 11 & Sandy silt & $C$ & $B$ \\
S22 & 27.6 & 43.7 & 22.41 & Sandy silt & $B$ & \\
\hline & & & & & & \\
\end{tabular}


Fig. 9 Rating of soil media map of the study area

Fig. 10 Rating of topography slope map of the study area
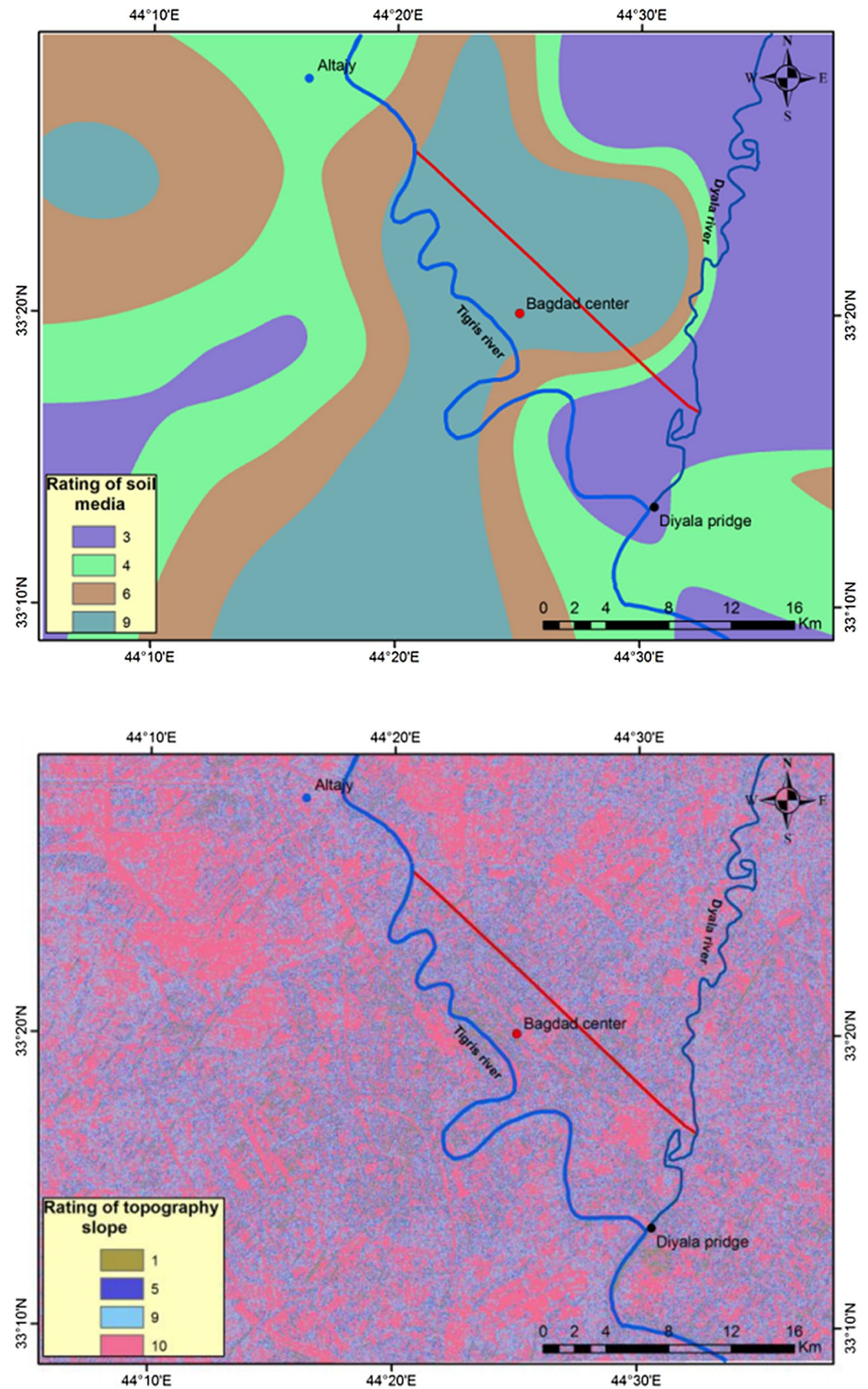

sensitive parameter to DRASTIC vulnerability is $R$ (net recharge), with mean value of 9.3 , followed by the $S, D$,
$C$, and $I$ of DRASTIC parameter, with mean value of 2.4, $2.2,1.9$, and 1.7 , respectively 
Fig. 11 Rating of vadose zone map of the study area

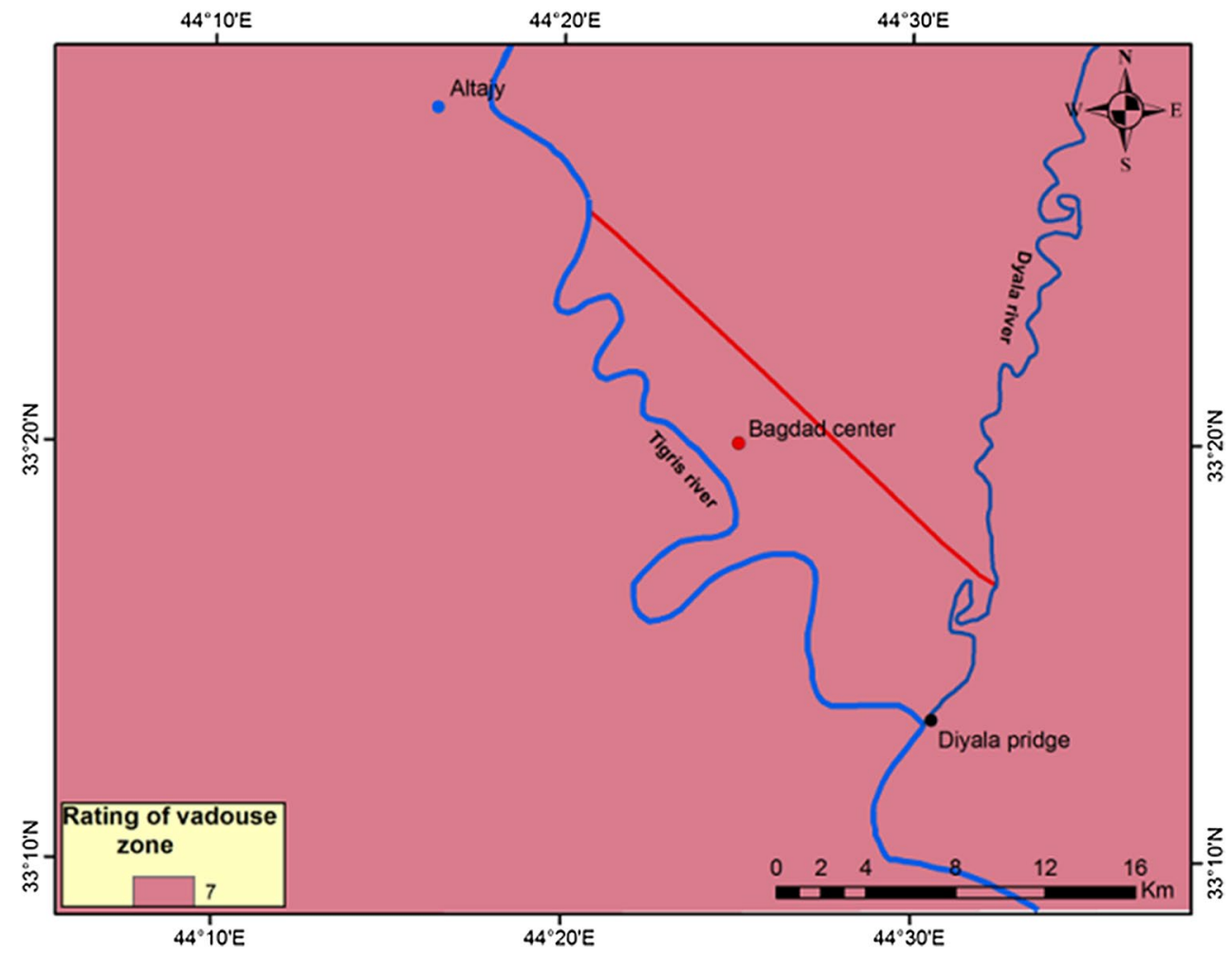

Fig. 12 Rating of hydraulic conductivity map of the study area

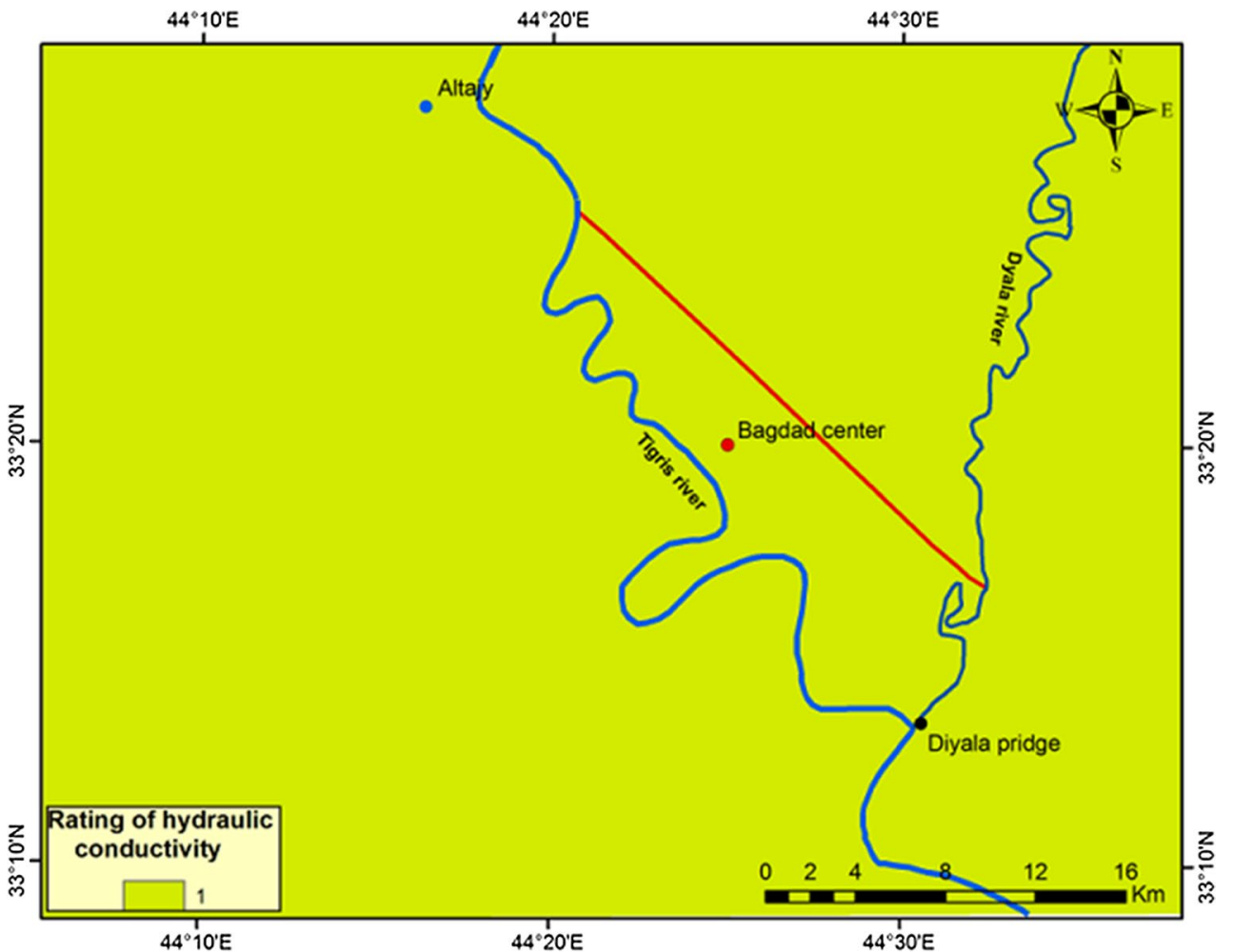


Fig. 13 Vulnerability index (Standard DRASTIC model) map of the study area
Fig. 14 Vulnerability index map (pesticide DRASTIC model) of the study area
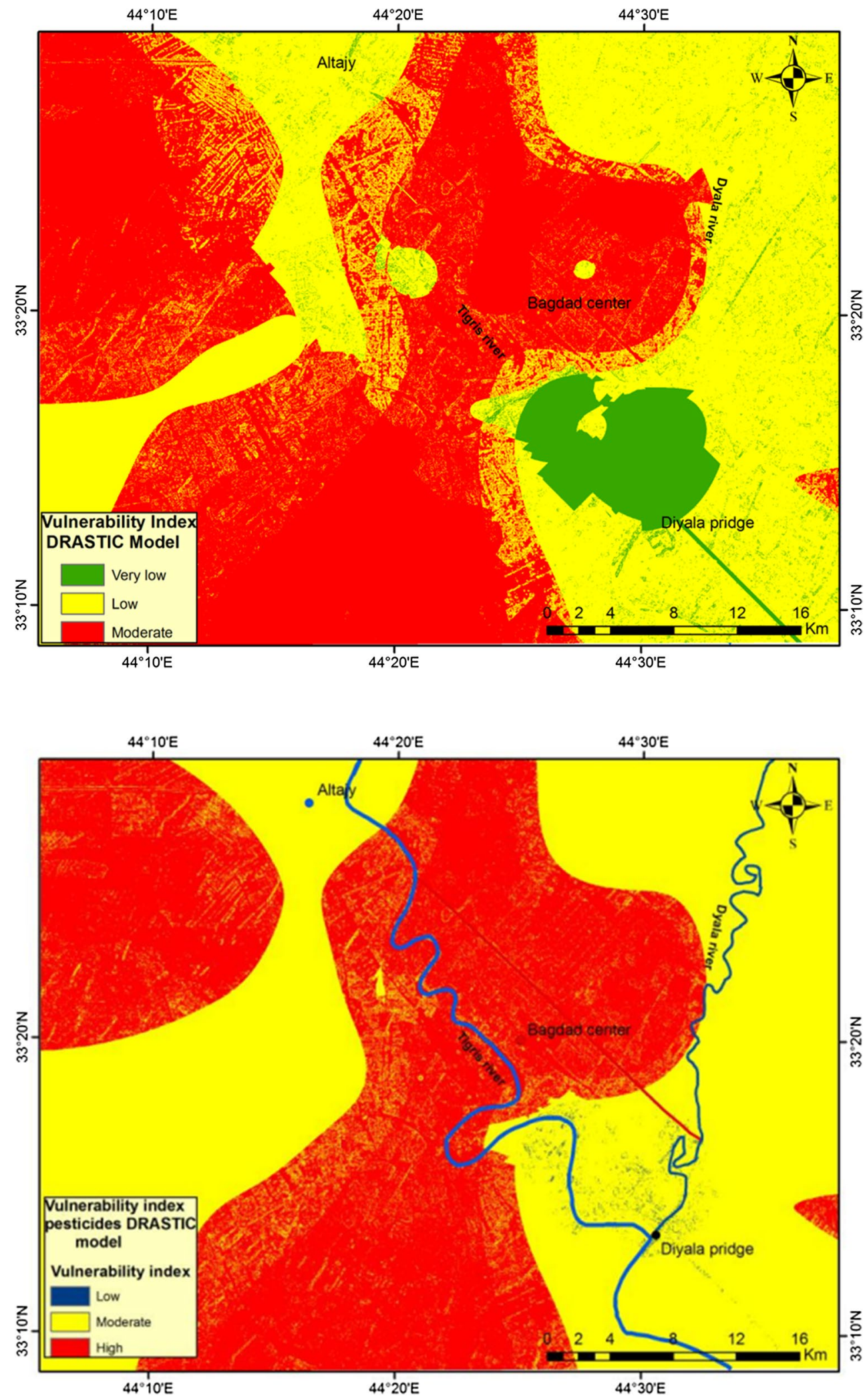
Table 7 Vulnerability classes of the study area

\begin{tabular}{llcr}
\hline DRASTIC conditions & Vulnerability classes & \multicolumn{2}{c}{ Area occupied } \\
\cline { 3 - 4 } & & $\mathrm{km}^{2}$ & $\%$ \\
\hline Standard & Very low & 110.5 & 5.7 \\
& Low & 747.15 & 38.4 \\
& Moderate & 1088.8 & 55.9 \\
Pesticides & Low & 27.2 & 1.4 \\
& Moderate & 982.55 & 50.5 \\
& High & 936.6 & 48.1 \\
\hline
\end{tabular}

Table 8 The statistical summary of the DRASTIC factors maps

\begin{tabular}{llrll}
\hline $\begin{array}{l}\text { DRASTIC } \\
\text { factors }\end{array}$ & Min & Max & Mean & $\begin{array}{l}\text { Standard } \\
\text { deviation }\end{array}$ \\
\hline$D$ & 7 & 10 & 9.28 & 1.72 \\
$R$ & 1 & 1 & 1 & 0 \\
$A$ & 8 & 8 & 8 & 0 \\
$S$ & 4 & 10 & 6.48 & 2.29 \\
$T$ & 1 & 10 & 8.69 & 2.25 \\
$I$ & 7 & 7 & 7 & 0 \\
$C$ & 1 & 1 & 1 & 0 \\
\hline
\end{tabular}

Table 9 Statistics on sensitivity to removing one DRASTIC parameter

\begin{tabular}{lllll}
\hline $\begin{array}{l}\text { Parameter of } \\
\text { sensitivity }\end{array}$ & Min & Max & Mean & $\begin{array}{l}\text { Standard } \\
\text { deviation }\end{array}$ \\
\hline$D$ & 0 & 4.3 & 2.2 & 0.81 \\
$R$ & 6 & 13 & 9.3 & 1.41 \\
$A$ & 0 & 2.4 & 0.86 & 0.55 \\
$S$ & 0 & 5 & 2.4 & 0.43 \\
$T$ & 1 & 2.6 & 1.5 & 0.69 \\
$I$ & 0 & 3.9 & 1.7 & 1.03 \\
$C$ & 1 & 4 & 1.9 & 0.71 \\
\hline
\end{tabular}

Table 10 Variation index of the excluded DRASTIC model parameter

\begin{tabular}{lllll}
\hline $\begin{array}{l}\text { Variation } \\
\text { index }\end{array}$ & Min & Max & Mean & $\begin{array}{l}\text { Standard } \\
\text { deviation }\end{array}$ \\
\hline$D$ & 0.15 & 0.48 & 0.24 & 0.043 \\
$R$ & 0.08 & 0.19 & 0.12 & 0.023 \\
$A$ & 0.11 & 0.31 & 0.17 & 0.031 \\
$S$ & 0.04 & 0.16 & 0.08 & 0.027 \\
$T$ & 0.17 & 0.28 & 0.20 & 0.020 \\
$I$ & 0.08 & 0.19 & 0.13 & 0.093 \\
$C$ & 0.01 & 0.23 & 0.11 & 0.070 \\
\hline
\end{tabular}

Another important factor that should be assessed by DRASTIC sensibility is the variation index $\mathbf{v}_{\mathbf{x i}}$ which is computed as follows (Gogu and Dassargues 2000):
Table 11 Statistics of the single-parameter sensitivity analysis

\begin{tabular}{llcc}
\hline Factor & $\begin{array}{l}\text { Theoretical } \\
\text { weight }\end{array}$ & $\begin{array}{l}\text { Theoretical weight } \\
(\%)\end{array}$ & $\begin{array}{l}\text { Effective } \\
\text { weight }(\%)\end{array}$ \\
\hline$D$ & 5 & 20.7 & 30.5 \\
$R$ & 4 & 16.4 & 3.1 \\
$A$ & 3 & 14.0 & 26.09 \\
$S$ & 2 & 8.3 & 12.74 \\
$T$ & 1 & 21.9 & 16.43 \\
$I$ & 5 & 5.4 & 8.73 \\
$C$ & 3 & 14.4 & 3.21 \\
\hline
\end{tabular}

$v_{x i}=\frac{v-v^{\prime}}{v}$

The negative value of variation index means that removal one of the parameter will increase the vulnerability values, thereby reducing the calculated vulnerability (Gogu and Dassargues 2000). As shown in Table 10, the result values are positive which means that the vulnerability index was reduced by removing one parameter of DRASTIC model and increasing the calculated vulnerability.

In order to evaluate the impact of each factor in DRASTIC model on the vulnerability index the analysis of effective weight should be achieved. This analysis compares the effective weight of each input factors in each polygon with the theoretical weight assigned by the analytic model (AlAbadi et al. 2017). The effective weight of each polygon is obtained using the following formula:

$W=\frac{P_{\mathrm{r}} P_{\mathrm{w}}}{v} \times 100$

where $W$ refers to effective weight for each factor, $P_{\mathrm{r}}$ is the rating values given for each parameter(factor), $P_{\mathrm{w}}$ is the weights assigned for each parameter, $v$ is the DRASTIC vulnerability index

Table 11 shows the statistics of the calculating effective weight for each DRASTIC factor. Calculations show that there is significant difference between the effective weights of DRASTIC factors and the assigned theoretical weight. Recharge $R$, impact of vadose zone $I$, and hydraulic conductivity $C$ are the highest differences. The lack or uncertainties in these factors will reflect the inconsistency that reduces the efficiency of the Vulnerability index model.

\section{Conclusion}

- DRASTIC model provides a good tool to evaluate and managing the groundwater systems for its vulnerability to contamination. 
- Intrinsic vulnerability by DRASTIC model was applied for the Quaternary aquifer of Baghdad city for pesticide and standard conditions; the results confirm that the DRASTIC index of pesticide conditions will access 33\% than DRASTIC index of standard conditions.

- The vulnerability index results for both conditions show high vulnerable areas at the middle and northwestern parts of the study areas which represents the most susceptible areas for pollution.

- The variation in topography, soil media and water depth considered the main factors that affect the distribution of vulnerability classes through the area.

- Controlling the domestic, agricultural, and industry activities in vulnerable areas are important in protecting the groundwater from pollution, in addition to monitoring the chemical, physical, and biological indicators that effects negatively in deteriorate the groundwater resources.

- It is important to test the consistency of the DRASTIC factors in the vulnerability assessment by validating and evaluating the sensitivity analysis in any study; the results show that the effective weight for each factor is different from the theoretical weights assigned by the DRASTIC model. The lack or uncertainties in recharge, impact of vadose zone, and hydraulic conductivity are the highest factors that reduce the efficiency of the vulnerability index model.

Open Access This article is distributed under the terms of the Creative Commons Attribution 4.0 International License (http://creativeco mmons.org/licenses/by/4.0/), which permits unrestricted use, distribution, and reproduction in any medium, provided you give appropriate credit to the original author(s) and the source, provide a link to the Creative Commons license, and indicate if changes were made.

\section{References}

Al-Abadi AM, Al-Shamma'a AM, Aljabbari MH (2017) A GIS-based DRASTIC model for assessing intrinsic groundwater vulnerability in northeastern Missan governorate, southern Iraq. Appl Water Sci 7:89-101

Al-Hiti BM (1985) Groundwater quality within Baghdad area, M.Sc. thesis, College of Science, University of Baghdad, p 235 (in Arabic)

Ali SM (2012) Hydrogeological environmental assessment of Bagdad area. Ph.D thesis. Bagdad Unv. Collage of Science, p 245

Ali SM, Al-Bassam SK, Al-Tawash S (2013) Geochemical and minerological analyses of recent Flodd Plain and River deposits in Baghdad-Iraq. Iraqi Bull Geol Min 9:97-129

Al-Jiburi H (2009) Hydrogeological conditions in Baghdad Governorate, GEOSURV, report no. 3163, Baghdad (internal report), p 54

Al-Jiburi HK, Al-Basrawi NH (2011) Hydrogeology. In: Geology of Iraqi southern desert. Iraqi Bull Geol Min, Special Issue, no. 2, p 77-91

Aller L, Robert SKERL, U.S. Environmental Protection Agency, Office of Research and Development (1987) DRASTIC: a standardized system for evaluating ground water pollution potential using hydrogeologic settings. Robert S. Kerr Environmental Research Laboratory, Office of Research and Development, U.S. Environmental Protection Agency, Ada, Okla

AL-Qurnawi WS (2014) Groundwater vulnerability assessment and well head protection zones of Alton Kopry Basin, Kirkuk Governorate Northeast of Iraq. Ph.D. thesis. Basrah Unv. Collage of Science, $\mathrm{p} 216$

Araim HI (1990) Regional hydrogeology of Iraq. GEOSURV, Int rep no 1450

Awadh SM (2015) Cd, Ni, and $\mathrm{Pb}$ distribution and pollution assessment in roadside dust from Baghdad City and Western Iraqi Desert. Arab J Geosci 8:315-323

Baalousha H (2006) Vulnerability assessment for the Gaza Strip, Palestine using DRASTIC. Environ Geol 50:405-414

Babiker IS, Mohamed MA, Hiyama T, Kato K (2005) A GIS-based DRASTIC model for assessing aquifer vulnerability in Kakamigahara Heights, Gifu Prefecture, central Japan. Sci Total Environ 345:127-140

Bashoo D, Lazim S, Alwan M (2005) Hydrogeology of Bagdad province, General Directorate of Water Well Drilling, Bagdad, (internal report), p 51

Civita M, De Regibus C (1995) Sperimentazione di alcune metodologie per la valutazione della vulnerabilità degli acquiferi. Atti $2^{\circ}$ Conv. Naz

Corniello A, Ducci D, Napolitano P (1997) Comparison between parametric methods to evaluate aquifer pollution vulnerability using GIS: an example in the "Piana Campana", southern Italy. Engineering geology and the environment. Balkema, Rotterdam, pp $1721-1726$

Daly D, Warren WP (1998) Mapping groundwater vulnerability: the Irish perspective. Geol Soc Spec Publ 130:179

Gogu RC, Dassargues A (2000) Sensitivity analysis for the EPIK method of vulnerability assessment in a small karstic aquifer, southern Belgium. Hydrogeol J 8:337-345

Hamamin DF (2011) Hydrogeological assessment and groundwater vulnerability map of Basara Basin, Sulaimani Governorate, Iraq, Kurdistan Region unpublished Ph.D. thesis, College of Science, University of Sulaimani, Sulaymaniyah

Jassim SZ, Goff JC (2006) Geology of Iraq. DOLIN, sro, distributed by Geological Society of London

Leal JAR, Castillo RR (2003) Aquifer vulnerability mapping in the Turbio river valley, Mexico: a validation study. Geofísica Internacional 42:141-156

Mendoza J, Barmen G (2006) Assessment of groundwater vulnerability in the Río Artiguas basin, Nicaragua. Environ Geol 50:569-580

Napolitano P, Fabbri A (1996) Single-parameter sensitivity analysis for aquifer vulnerability assessment using DRASTIC and SINTACS IAHS. Publ Ser Proc Rep Intern Assoc Hydrol Sci 235:559-566

Rawls WJ, Brakensiek D, Saxtonn K (1982) Estimation of soil water properties. Trans ASAE 25:1316-1320

Salman A, Sultan SA, Ibrahim IM (1990) The study of ground water level and engineering characteristics of Baghdad Soil. Amanat Baghdad, Republic of Iraq, p 382p

USDA Soil conservation service, Soil Survey Staff (1975) Soil Taxonomy: a basic system of soil classification for making and interpreting soil surveys, USDA agriculture Handbook, $754 \mathrm{p}$

SCS U (1986) Urban hydrology for small watersheds, technical release no. 55 (TR-55) US Department of Agriculture, US Government Printing Office, Washington, DC

Yacoub SY (2011) Stratigraphy of the Mesopotamia Plain. Iraqi Bull Geol.Min. Special Issue, No.4, pp 47-82

Publisher's Note Springer Nature remains neutral with regard to jurisdictional claims in published maps and institutional affiliations. 